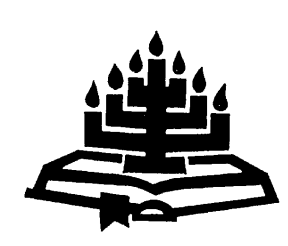

\title{
'n Werkgroep vir teologie, filosofie en ander vakdissiplines
}

\author{
P.G.W. du Plessis \\ Eenheid vir Reformatoriese Teologie \\ Potchefstroomkampus \\ Noordwes-Universiteit \\ POTCHEFSTROOM \\ E-pos: pgwdup@lantic.net
}

... no truth is arrived at without the scientist assuming (or having faith in) a particular worldview ...

So the faith component, so important in religion, has its counterpart in science.

Stannard, 2000:170.

\section{Abstract}

\section{A workshop for theology, philosophy and other disciplines}

The proposal to start a workshop among theologians, philosophers and other specialists is connected to the view that foundational issues exist in every faculty and in every field of study. A distinction between theology as "divinity knowledge" and philosophy as "secular rational discourse" is set aside by explaining that both theology and philosophy are "sciences of faith". Not one single discipline is without its bona fides and its foundational issues. Hence, the suggestion to pay continual attention to foundational issues in theology, philosophy and other concerned disciplines in an interdisciplinary workshop.

Using the so-called multidimensional scope of science (empirical, methodological and dimension of meta-issues) the author argues that any scientific discipline is inextricably bound up with foundational issues.

Some limitations and some advantages of scientific inquiries like logical critique, transcendental critique, and transforming of elements of truths serve as to deliberately further co-operation between specialists on common fundamental issues, on inadmissible/undesirable differences and on indispensable diversity.

Several assumptions are presented, for example one's own specialist field does not have the final word about common issues; that various specialists can learn from one another; 
Christian theology does not render Christian scholarship redundant in other scientific disciplines such as languages or philosophy.

Special disciplines deteriorate in scientific quality whenever specialists tend to get rid of their inherent foundational issues, tend to keep quiet about them, or pass them on to philosophers.

\section{Opsomming}

\section{'n Werkgroep vir teologie, filosofie en ander vakdissiplines}

Die voorstel dat 'n werkgroep tussen teoloë, filosowe en ander vakspesialiste op die been gebring word, hang nou saam met die insig dat grondslaekwessies in alle fakulteite en studierigtings bestaan. Die skrywer beweeg weg van die onderskeid dat teologie "sakrale geloofswetenskap" en filosofie "sekulêre rasionele diskoers" is. Teologie en filosofie kan nie sonder "geloof" en grondslaekwessies beoefen word nie. Daarom kan bona fides en grondslaekwessies interdissiplinêr deurlopend in 'n werkgroep aandag kry.

Vanuit die meerdimensionele opset van wetenskap (empiriese, metodologiese en dimensies van metakwessies) beredeneer die skrywer dat wetenskaplike dissiplines simbioties aan grondslaekwessies verbind is.

Beperkings en voordele van logiese, transendentale en transformasionele kritiek word gebruik om opsetlike samewerking tussen betrokke vakgeleerdes te bevorder oor gemeenskaplike sake en oor nodige én onwenslike verskille tussen die dissiplines.

Verskeie aannames kom ter sprake, soos dat die eie vakrigting nie alles oor sogenaamde gemeenskaplike kwessies te sê het nie; dat die onderskeie vakgenote by mekaar kan leer; dat Christelike teologie nié 'n Christelike denke in ander dissiplines soos taalwetenskappe en filosofie oorbodig maak nie.

Vakspesialiste verarm hulleself indien hulle ontslae wil raak van hulle vak-inherente grondslaekwessies, daaroor swyg of dit aan filosowe afstaan.

\section{Inleiding}

Ter huldiging van prof. Tjaart van der Walt maak hierdie artikel 'n voorstel om 'n opsetlike wisselwerking tussen beoefenaars van (gereformeerde, Christelike of bybelse) teologie en (reformatoriese of Christelike) filosofie te help bevorder. Vir prof. Van der Walt is die reformatoriese manier van dink en doen prinsipieel vreemd aan 'n hokkie- en vakkiedenke. Daarom sou 'n interdissiplinêre aanpak van 
grondslaekwessies moontlik sy positiewe aandag trek. As wetenskaplike dissiplines staan genoemde teologie en filosofie in hulle gemeenskaplike strewe na Christelike denke en kennis ook voor talle gemeenskaplike probleme en take. Die strewe na eensgesindheid waarvan Fillipense 2:2 melding maak (vgl. Die Bybel, 2004: 1552), kan ook 'n bron van inspirasie wees vir Christenteoloë en Christenfilosowe om eerder op die dinge waaroor hulle saamstem (of behoort saam te stem!) te konsentreer.

\section{Van outoritêr afgrens tot saamwerk}

'n Oorsig van die dialoë tussen (Westerse) Teologie en Filosofie met toepaslike onderwerpe en denkskole is ondoenlik binne die bestek van hierdie artikel. Daar was tye toe Thomas van Aquino 'n Christelike teologie en 'n redelike Aristoteliese filosofie vreedsaam in een wetenskapsgebou met 'n grondverdieping (filosofie) en 'n bobou (teologie) apart laat woon het. Sedert die Middeleeue tot vandag was en word daar voorskriftelike én simpatieke gesprekke tussen teoloë en filosowe gevoer - meermale oor die verhouding tussen "geloof en rede". From conflict to conversation, die subtitel van Haught (1995) se boek, gee 'n idee van die spektrum van standpunte. In sy oorsig sê Wolterstorff (1996:200 e.v.) onder andere dat sienings van skeiding tot in moderne tye voorkom.

Door de eeuwen heen hebben denkers geprobeerd geloof en wetenschap afzonderlijke terreinen toe te wijzen. Ze hebben daartussen geprobeert schuttingen te zetten ..., sloten te graven en dijken te bouwen ...

Daar was tye dat Teologie as (selfverklaarde) koningin van die wetenskappe, dominerende stellings oor Filosofie - en die lewe - geformuleer het. Filosofiese kritiek daarop het teologie as bemiddelaar (tussen gelowiges en die Bybel) teruggesnoei tot 'n agterbanker. Binne die reformatoriese Wysbegeerte van die wetsidee, het filosofie soms die rol van bemiddelaar tussen die (gelowige) mens en die Bybel begin speel. Teoloë bestempel filosofie as te sekulêr vanweë teologiese bloedarmoede en filosowe bestempel teologie as te onwetenskaplik en skolasties - vanweë filosofiese bloedarmoede. 'n Filosofiese begronding is voorwaardelik vir goeie teologie (vgl. onder andere Ouweneel, 1995; Troost, 2004:147 e.v.).

Naas bogenoemde word soms in die wandelgange van akademiese instellings die volgende soort opmerking gehoor: al rede waarom studente in Teologie nog 'n kursus in Filosofie moet neem, is om beter kennis van filosofiese dwalings in die teologie te dra. Soms het 
die beterweterige advies van filosowe juis ander wetenskaplikes vervreem, sodat vakspesialiste die filosowe as sogenaamde metafisikaliefhebbers genegeer het deur meermale positivisties skeiding te maak tussen feite en waardes:

De feitelike praktijk van de wetenschap heeft zich nooit veel aangetrokken van algemene apriorische voorschriften, die door filosofen aan wetenschappers werden voorgehouden. ... Wetenschappers gingen hun eigen gang en hebben de filosofen gewoon genegeerd ... (Wolterstorff, 1996:58).

Voorbeelde van 'n koue oorlog met min dialoog en meer skepsis teenoor mekaar - 'n denkmodel van uitsluiting en konfrontasie - is veral in die Modernisme opgestel (deur filosowe en teoloë) sodat filosofie as "a-teïstiese kennis" teenoor teologie as "heilige godgeleerdheid" beskryf en bedryf is. Veral sedert die Verligting (of Modernisme) word filosofie as 'n kennis van die wêreld sonder God en teologie as 'n kennis van God los van die wêreld beoefen. Uitdrukkings soos "die God van die Bybel en die god van die filosofie", beskryf nog 'n aversie tussen sommige teoloë en filosowe.

Laasgenoemde opmerking hoef egter nie die slotakkoord tussen teologie en filosofie te wees nie. Die Calvinistiese filosoof Stoker soek byvoorbeeld samewerking op die basis van differensiasie tussen Teologie en Filosofie en dat die een wetenskap nie die ander mag oorheers nie. Stoker (1970:40) sê dit is verkeerd

... dat die Teologie ander wetenskappe aan hom onderwerp het, dat die Wysbegeerte aan ander wetenskappe voorgeskryf het en dat die vakwetenskappe (soos bv. die Natuurwetenskappe) diktatoriaal teenoor ander wetenskappe opgetree het.

Enige oorsig van die variasies kan baat vind by die beskeie waarskuwing van Haught (1995:12).

No simple formula can adequately describe the rich, thickly textured, and complex relation between Christianity and Western science.

Dit is bekend dat die modernistiese skeiding tussen wetenskap en geloof opgevolg is deur postmodernistiese beklemtonings van integrasie tussen godsdiens en wetenskap, tussen waardes en feite. Haught (1995) wys op sterk voorwetenskaplike ladings in die talle variasies in die verhouding tussen geloof en wetenskap in periodes na die Verligting. Selfs die betrokke modernistiese en postmoder- 
nisiese ladings kan as gemeenskaplike opgawe vir die werkgroep dien.

Postmodern science, ... finds its best expression in postpositivist, historicist ... philosophies of science, which have revealed the theory-laidenness of all data, and the shaping role of epistemic and non-epistemic value-judgments in the scientific process. Postmodern philosophy of science also reveals the narrative and hermeneutical dimension of science to us by acknowledging that science itself is a truly cultural and social phenomenon. (Van Huyssteen, 1998:15.)

\subsection{Tekorte van immanente kritiek}

Hierdie artikel onderstreep die wenslikheid van dialoog tussen filosowe en teoloë met 'n gemeenskaplike strewe na Christelike denke, met inagneming van pertinente verskille in veral studievelde en metodes van ondersoek. Omdat daar binne reformatoriese kringe onderlinge meningsverskille oor veral studievelde en metodes van ondersoek bly voortbestaan, word ook aandag gegee aan gesprek met andersdenkendes.

Gesprekke met andersdenkendes word gemaklikheidshalwe in drie groepe verdeel, naamlik 'n eksklusiewe, 'n inklusiewe en 'n pluralistiese groep. Die eksklusiewe groep gebruik meestal die metode van logiese kritiek om standpunte antiteties teenoor mekaar te omlyn. Hier is meer sprake van eksklusivisme of afgrensing en min sprake van die akkommodering van die opponent.

Gesprekke oor verskille tussen teoloë en filosowe is reeds meermale aangepak. Teoloë en filosowe is egter soms geneig om eerder te begin en te volstaan met gangbare verskille in probleemstellings, in metodes van die aanpak van die gesprekke, en in denkskole. Dit bly nuttig dat teoloë en filosowe van "dieselfde groep" dialoog kan voer deur mekaar se opvattings met behulp van selfkritiek en immanente kritiek te beoordeel.

Immanente kritiek maak baie gebruik van die reëls van die logika. Hier vra wetenskaplikes dikwels na die "logiese konsekwentheid" van 'n teorie. Die kritiese gesprek met ander kollegas konsentreer op rasionele logiese samehang. Wetenskaplike A kan kontroleer of $B$ miskien meer as een betekenis aan dieselfde begrip heg. Verder kan gevra word of die teorie 'n samehangende sisteem is en of die konklusie dalk 'n sirkelredenasie is. 
Immanente kritiek handel meestal met 'n rasionalistiese verstaan en veronderstelling van "goeie wetenskap". Die afgelope 40 jaar is egter baie aan die begrip en proses van wetenskap verander. Wolterstorff stel dit reguit dat moderniste (insluitende rasionaliste en positiviste) 'n hoë premie op wetenskap as 'n rasionele, logiese sisteem geplaas het:

Characteristic of the modern academy in general has been a regnant understanding of the structure or, if you will, 'the logic' of well-formed Wissenschaft. The past quarter-century has witnessed the shattering of that regnant self-understanding; that's what makes the academy today very different from what it was forty years ago. ... Perhaps the deepest component in this understanding was the conviction that well-formed learning is a generically human enterprise ... before entering the halls of learning we are to render inoperative ... all our particularities of gender, ... of religion, of social class ... (Wolterstorff, 2002:6).

'n Logiese sisteem is egter self geen bewys van 'n ware opvatting van sake nie, omdat dit as abstraksie losgemaak is van die werklikheid. Geertsema waardeer logiese wetenskap, maar verwerp die ideaal van absolute rasionele kennis.

Clearly, knowledge obtained through defined concepts and logical rules opens up reality to deeper insights in a certain way. But this does not mean that reality is thereby revealed in its true form. ... Reality is more than rational (Geertsema, 1996:304305; kursivering - PGWdP).

Thomas Kuhn toon in sy boek oor die struktuur van wetenskaplike revolusies aan dat daar nie voldoende gemeenskaplike rasionele kriteria bestaan waarvolgens verskillende denkskole mekaar logies kan oortuig nie. Vanuit die Christenwetenskaplike benadering is nog altyd gestel dat logiese redes nooit voldoende is om ' $n$ verwerping van een paradigma en die aanvaarding van 'n ander paradigma te motiveer nie. So kan geen wetenskaplike weerlegging van (of bewys vir) die Christelike geloof gelewer word nie. Die menslike rasionele bewyse wat dit tog probeer doen, word immers self deur 'n spesifieke geloof aan die outonomie van die menslike rede gedra. Hier is dit geloofsveronderstellings wat wetenskaplike bewyse sanksioneer of rig - en nie andersom nie! Wetenskap is geen onafhanklike, neutrale, objektiewe, geloofslose of veronderstellingslose toegang tot die werklikheid en tot betroubare geldige kennis nie.

Immanente, rasioneel-logiese kritiek is egter nie waardeloos nie. Selfs teologie en filosofie soek na intersubjektiewe geldigheid en lo- 
giese antwoorde. Teologie en filosofie kan nie sonder kritiese kommunikasie uitgebou word nie. Rasionaliste oordryf wel die rol van rasionele denke en vind die beginpunt van wetenskap in die menslike denke self. Formele of rasionele logika is nie genoeg om wetenskaplikes 'n betroubare insig in die dinamiese werklikheid van hulle studievelde te gee nie.

In his now-famous book, The Structure of Scientific Revolutions, Kuhn argued that revolutions in science do not occur because some new theory is discerned to be more probable than the old theory on evidence accepted by all parties; nor - to bring Karl Popper into the picture - because the old theory has been falsified. Instead, something like conversion takes place. Kuhn himself borrowed religious language at this point. (Wolterstorff, 2002:9.)

'n Voordeel van kritiek wat op verskille let, is dat gespreksgenote sodoende tog groter (logiese) duidelikheid kry as hulle mekaar se standpunte kontrasteer en duidelik skeidslyne trek. Die neiging om egter met "verskille" en "foute" te volstaan, kan maklik 'n gevoeligheid vir talle gemeenskaplike vraagstukke en projekte kortwiek. Dan word aanneemlike uitsprake (waarheidselemente?) van gedagtes by die ander (Christelike) denker nie maklik raakgesien of toegejuig nie. Daarom die vraag: Kan gespreksgenote verder vorder as net tot by die stasie waar hulle "ooreenstem om te verskil"?

\subsection{Tekorte by filosofie en teologie: lastig én gunstig vir samewerking}

Gesprek tussen Teologie/teoloë en Filosofie/filosowe word meestal bemoeilik deurdat elkeen 'n "anderste" opvatting het van die eie werkterrein, asook van die werkterrein van die gespreksgenoot. Daarom word in hierdie verband voorgestel dat die leerstuk van "verskil in studieterrein en metode" nie losgemaak kan word van die moontlikheid dat die betrokke studieterreine dig bymekaar op dieselfde spektrum lê nie. Hier word nie voortydig 'n eie siening van die studieterreine van Filosofie en Teologie in detail verskaf nie. Groter duidelikheid daaroor kan 'n resultaat van die gesprekforum wees.

Teoloë en filosowe erken dat hulle slegs ten dele ken en dat hulle daarmee op weg is na betroubare kennis wat meer is as logiese waarheid. Hierdie gedeeltelike kennis kry 'n eskatologiese betekenis wanneer die mens en die res van die skepping ten volle geken sal word. Alleen God ken die dinge soos dit is, gaan word en sal verdwyn. 
Omdat die werklikheid ryker is as menslike rasionele konstruksies, moet die vraag gestel word of daar in (gereformeerde) teologiese en (reformatoriese) filosofiese studies nog plek vir misterie en relevansie is - naas rasionaliteit en logiese waarheid. Waarheid is meer as wat wetenskaplik bewys kan word. Waarheid is ook meer as subjektiewe oortuiging.

Modernisme soek na 'n omvattende rasionele opklaring van ongerymdhede (vgl. onder andere Claassen, 2007). Postmodernisme is egter daarteen gekant, omdat die werklikheid irrasionaliteit uitspel. Postmoderne opmerkings dat geen groep wetenskaplikes die rasionele vermoë het om die werklikheid omvattend, uitputtend, volledig of adekwaat te leer ken nie, is ook waar. Die motivering van postmodernisme dat die werklikheid (insluitende die kennende mens) basies irrasioneel, onlogies, relatief, diskontinu en chaoties van aard sou wees, word verwerp. As motivering word kollegas eerder verwys na die komplekse verskeidenheid en samehang binne die skepping wat basies kreatuurlik, relasioneel, ordelik, a-rasioneel, vol wonderlike misterie is en tog deels kenbaar, bewerkbaar en ontplooibaar is.

Teoretiese kennis is tegelyk die krag en die achillishiel van elke wetenskap. Dit kan slegs een soort kennis (teoretiese kennis) verskaf. Verder is dit bloot 'n denkbeeldige (re-)konstruksie van die kenbare werklikheid. Wetenskaplike kennis is geen konkrete duplikaat van die werklikheid nie; dit toon altyd 'n tekort.

Elke vakdissipline het grense vanuit die eie studieveld. Eenvoudig gestel: Taalkunde bestudeer tale en Dierkunde bestudeer diere. Geen wetenskap kan die universum omvat nie. Vakkennis gee 'n abstrakte denkbeeld van die werklikheid. Alle wetenskaplike dissiplines, selfs Teologie en Filosofie, is 'n maer spookgedaante, of 'n vreemde rekonstruksie van die werklikheid. Geen wetenskaplike studie, afsonderlik of gesamentlik, is in staat om die oorsprong, sin en doel van die werklikheid te definieer nie. Die skepping is ten diepste 'n geheim. Laasgenoemde is 'n voorwetenskaplike geloofsantwoord waarop ons wetenskap 'n beroep doen (vgl. Ellis, 2000:165).

Dit beteken dat wetenskaplike kennis (teologies, filosofies, vakwetenskaplik) sydig, betreklik, voorlopig, oop en stamelend is. Die grense van vakdissiplines het veral te make met wat Geertsema die menslike karakter van die soeke na kennis noem (vgl. Geertsema, 1992). Selfs natuurwetenskaplikes skerts oor 'n wesenlike beperking in die Wiskunde. Einstein het op 'n keer glo opgemerk: 
... as far as the propositions of mathematics refer to reality, they are not certain; and as far as they are certain they do not refer to reality (Newbigin, 1989:29).

Genoemde tekorte beteken nie dat wetenskaplike kennis 'n leuenverhaal oor die werklikheid is nie. Erkenning van beperkende grense in en van wetenskaplike kennis sluit nie uit dat erkenning juis aan soveel waarde, waarheid en goeie kwaliteite in en van die onderskeie dissiplines gegee word nie.

\section{Aannames nodig vir interaksie}

Indien wetenskaplikes werk maak van die aanname dat antwoorde van die eie vakgebied relatief en konteksgebonde is, stel hulle hulleself oop vir insigte deur ander wetenskaplikes met ander raamwerke. Die eie identiteit, studieterrein, metodiese styl en eie kognitiewe sisteem van die vakbeoefening word nie daardeur opgehef nie. Dit word eerder deur die betrokke komponente verryk en gerelativeer. In die praktyk word wetenskap deur konkrete, lewende mense gemaak en nie deur 'n rasionaliteit of swewende rede wat slegs feitekennis versamel nie.

Waar meningsverskille tussen Christendenkers bestaan, kan dit die moeite werd wees om vanuit dit waarmee hulle ooreenstem, na verskille te kyk. Die voorstel dat wetenskaplike dissiplines soos onder andere Teologie en Filosofie saamwerk, word in die artikel aangevoor vanuit ' $n$ aantal uitgesproke of geïmpliseerde bewerings.

- Geen vakdissipline bestaan sonder 'n dimensie van grondslaekwessies nie.

- Nog Filosofie, nog vakdissiplines het 'n alleenreg op sogenaamde grondslaekwessies.

- Die eie vakrigting het nie alles te sê oor sogenaamde gemeenskaplike kwessies nie. Die eie vakgebied het wel iets te sê oor ander vakgebiede.

- Die onderskeie vakkundiges kan by mekaar leer. Die eie vak ken ten dele. Daarom is samewerking ook tussen Christelike denkers nodig.

- Die eie vakkennis is 'n voorlopige, afhanklike, hersienbare en ken-ten-dele-kennis. Wetenskaplike waarheid is slegs 'n gedeeltelike waarheid. 
- Elke wetenskaplike dissipline is meer as net gesistematiseerde feitekennis. Wetenskap behoort 'n wete met 'n gewete te wees.

- Wetenskaplikes wat hulle dissipline benader en beoefen as kennis wat moreel verantwoord moet word as kennis wat nuttig en betreklik is en as kennis wat nie allesomvattend is nie, is reeds met grondslaekwessies in hulle dissiplines besig.

- Wat wetenskap finaal is/behoort te wees, kan nie wetenskaplik rasioneel deurgrond word nie.

- Teologie en Filosofie kan (moet) as wetenskappe tegelyk 'n teoretiese sowel as 'n prakties-relevante bydrae ontwikkel.

- Sonder bona fides, is daar geen wetenskaplike kennis nie.

- Kommunikasie tussen andersdenkendes en eendersdenkendes is ook moontlik, omdat wetenskap deur geloof "onderbepaald" is.

- Filosofie sowel as Teologie is/behoort wetenskaplike dissiplines te wees.

- Die werklikheid is ryker bedeeld as wat een wetenskap kan ontgin.

- Geen wetenskaplike het algehele insig in alle dinge nie - selfs nie die filosofiese denker wat soms as 'n universele wetenskaplike beskryf word nie.

- Christen en nie-Christen is aan dieselfde strukturele ordes van navorsing en onderrig onderhewig.

God het nie twee wêrelde - een vir gelowiges en een vir ongelowiges - geskep nie. Die wette van sy reën (hoogdruk, vog, temperatuur) geld vir gelowiges en vir goddeloses. In hulle vakdissiplines het wetenskaplikes met die een wêreld van God en sy ordes daarvoor te make. Ook die ateïs werk in God se wêreld (vgl. die strekking van die artikel van Du Plessis, 2006).

'n Bona fide aanname vir Christendenkers is dat die ganse skepping ook ' $n$ samehangende verskeidenheid is. Filosofie en Teologie kan (en moet) vanuit die onderskeie studievelde met mekaar in wisselwerking tree. Filosofie en Teologie hoef nie na mekaar gereduseer te word nie. Bybelse teologie maak 'n Christelike filosofie (of 'n Christelike denke in ekonomiese wetenskappe, taalwetenskappe en natuurwetenskappe) nié oorbodig nie. Christelike filosofie is geen verteologisering van die Filosofie nie. 
Beteken Christelike wetenskap eerstens en laastens die onderrig in die Christelike geloof? Sistematiese kennis en studie van Christelike oortuigings en van die ('n) Christelike leer kan 'n soort Christelike wetenskap wees. 'n Wetenskap word nie Christelik omdat dit Christelike onderwerpe bestudeer nie. Indien Christelike wetenskap slegs die onderrig en studie van Christelike geloofswaarhede sou beteken, dan sou byna net Bybelkunde of teologie(-se dissiplines) as Christelike wetenskappe kwalifiseer. Filosofie én Teologie probeer soms om geloof te monopoliseer. Geloof is egter meer as 'n soort wetenskaplike kennis van God, die mens en die wêreld. Tog maak geloofskennis (selfs bona fides) inherent deel uit van enige wetenskaplike kennis.

'n Simpatieker dialoog kan bevorder word indien daar op 'n vraagstuk gelet word waarvoor 'n gereformeerde teologie en 'n reformatoriese filosofie gemeenskaplik gestel word: Wat is die betekenis van die bybelse boodskap (en van Christene se evangeliese geloof) vir die sosiale, kulturele, politieke en talle ander lewensgebiede van die mens - waaronder onderwys en wetenskap? 'n Strategiese aanname by Newbigin (1989) en andere is dat Teologie (en Filosofie) relevant wil (moet) wees.

Resente vraaggesprekke oor die (praktiese) relevansie van teologiese en filosofiese kennis in en vir die menslike lewe en kultuur loop dikwels uit op 'n omgekeerde vraag: Hoe beïnvloed vandag se samelewing en kultuur met sy armoede, omgewingsbesoedeling, misdaad, ekonomiese krisis en magspolitiek die teologiese en filosofiese kennis - selfs die verstaan van die evangeliese boodskap?

Die voorstel dat samewerking oor die boeg van gemeenskaplike kwessies gegooi word, moet steeds met nodige - en onnodige verskille in werksterreine en in metodes tussen filosofiese en teologiese dissiplines rekening hou. Uiteindelik staan dit die gespreksforum vry om self die inhoud, vorm, grootte en moontlike werkswyse van die groep te bepaal. Vooraf konsensus oor plek, status, oop-toe karakter, ensovoorts waarborg nie dat die gespreksforum 'n plek is waar konflik gou ontlont gaan word nie.

Teologie en filosofie wil die mens en die wêreld in hulle konkrete leefwêreld opsoek en daarmee gesprek voer. Dit skep hermeneuties en epistemologies 'n groot ondersoekveld vir 'n interdissiplinêre span teoloë en filosowe sowel as vakkundiges soos historici en taalkundiges. 'n Gemeenskaplike vraag aan filosofie en teologie is byvoorbeeld hoe elkeen rekening hou met die historiese konteks van die werklikheid sonder om slagoffer van die geskiedenis te 
word. Anders gestel, hoe historisme en relativisme vermy word in die uitwerk van en dankbare jubeling oor die betekenis van die blye boodskap vir en in ons tyd.

Hier waag ek 'n bona fide antwoord: Dat Gods Gees mense in alle tye lei en in staat stel om in die eie veranderende omstandighede ook nuwe toepaslike betekenisse te verstaan en te ervaar (saam met bestaande betekenisse), en om die nuwe toepaslike betekenisse uit te werk met stamelende vertroue. Noll (2002:163) sê tereg: "... the epistemological assurance provided by Christian belief is a confidence attended with much humility".

Wanneer die kerninhoud van die Christelike geloof van die wetenskaplike 'n toepaslike rol in die verstaan en interpretasie van die studievelde (hetsy taal of ekonomie of kerk of natuur) speel, is vakkundiges beskeie besig met 'n Christelike benadering in hulle dissiplines.

Sommige Christendenkers (o.a. teoloë en filosowe) staan baie negatief teenoor pogings om 'n "brug" na andersdenkendes te bou. Die rede hiervoor is dat onbybelse gedagtes hierdeur 'n Christelike denkgemeenskap kan binnesluip. Die bestaan van sogenaamde waarheidselemente by andersdenkendes word ten strengste ontken: Jerusalem en Athene, geloof en ongeloof staan in konfrontasie teenoor mekaar.

Daarteenoor veronderstel heelwat Christendenkers dat daar wel 'n weg vanaf Jerusalem na Athene loop. Wolterstorff verskil van kollegas wat sê dat kommunikasie en redenasie tussen andersdenkendes futiel is. Sy rede is dat diegene wat van 'n mens se eie besondere perspektief verskil

... are often capable of discerning dimensions of reality that escape those who share one's own narrative identity (Wolterstorff, 2002:15).

Ook Dooyeweerd soek kommunikasie met andersdenkendes deur sy transendentale kritiek.

\section{4. 'n Beter verstaan: transendentale kritiek én hergebruik van waarheidselemente}

Met sy transendentale kritiek op die teoretiese denke het Herman Dooyeweerd in sy bekende Wijsbegeerte der wetsidee (in Engels vertaal as $A$ new critique of theoretical thought) begin vra na grondmotiewe van ons (Westerse) kultuur en wetenskappe. Dooyeweerd 
se filosofie bied dus 'n religieuse bepaaldheid as gemeenskaplike voorwaarde van die teoretiese denke om uiteindelik diskussie met andersdenkendes op dreef te kry. Kritiek van teoloë en filosowe dat religieuse bepaaldheid eerder kommunikasie belemmer as bevorder (vgl. onder andere Brummer, 1992), word vir die doel van hierdie artikel buite bespreking gelaat, omdat die positiewe uitkoms van Dooyeweerd se filosofie juis die belang van vooronderstellings vir kommunikasie aandui.

Transendentale kritiek laat gespreksgenote na dieper motiewe en begronding vra. Op grond waarvan sê A sus en B so? Wat is hulle uiteindelike begronding? Waarop begrond hulle die redenasies? Watter vooronderstellings huldig hulle? Transendentale kritiek (soms grenskritiek genoem) vra na gronde, voorwaardes, aannames, motiewe, bona fides, grense en kontekste in die wetenskap. Transendentale kritiek probeer na die diepste oortuigings of die laaste gronde delf wat wetenskaplikes (gewoonlik stilswyend en in stille vertroue) vir hulle beskouings aanvaar. Kritiek is ook 'n uitsif van en soeke na daardie bona fides of gronde waarvoor geen verdere redes of begronding aangegee kan word nie.

Die vraag na motiewe en begronding veronderstel dat daar "iets diepers" agter die wetenskaplike konklusies, agter die wêreld, die mens en sy kennis, kan wees. Gestel die werklikheid is die ene oppervlak sonder diepte, dan sou slegs oppervlak bestaan. Dit is hoe postmoderniste (en moderniste) redeneer. Albei is aanhangers van sekularisasie en omhels 'n anti-metafisika. Deurdat postmodernisme van die bo-aardse, die bonatuurlike en die metafisiese afsien, skep dit onbedoeld ruimte vir 'n nuwe religie wat slegs op die natuur (naturalisme) en die mens (humanisme) terugval. Met relativisme en sekularisme as leitmotief kom die kritiese vraag na vore, naamlik hoe dialoog en kommunikasie in die wetenskap dan nog moontlik is en hoe 'n humane samelewing nog moontlik is (vgl. Du Plessis, 2006:59).

Kollegas kan andersdenkendes maklik as ketters afmaak en so die gesprek beëindig. Postmoderniste kan gou verklaar "anything goes" en sodoende die gesprek as verligte pluralisme opskort (vgl. Bernstein, 2002:151). Sommige neo-Calvinistiese voorstanders van die antitesegedagte waarvolgens "twee soorte mense" (gelowiges en afvalliges) ook twee soorte wetenskap meebring, vermy enige sintese tussen Christelike en nie-Christelike denke. 
Wolterstorff en andere kapitaliseer egter op die bekende gedagte om waarheidsmomente by andersdenkendes te erken - veral vanweë God se algemene genade:

It also allows us to recognise the real similarities and commonalities between Christian and non-Christian scholarship ... (Sloane, 2003:125).

Diepgaande kritiese debatte het al plaasgevind deur na sogenaamde waarheidselemente by andersdenkende kollegas te soek. Die voorstel om eerder gevoelig te wees vir bruikbare, goeie en ware insigte by ander vakgenote, sluit aan by Klapwijk (1995) se idee van "transformasionele" filosofie. Daarvolgens moet (Christelike) filosofie sekere "heidense" denkinhoude losmaak van die betrokke konteks, dit omsmelt en binne die Christelike konteks gebruik. Klapwijk wil die waarheidselemente van andersdenkendes skei van hulle ideologiese konneksies en dit sodoende na 'n Christelike gedagte transformeer en verander. 'n Christelike verwerking of omsmelting van byvoorbeeld humanistiese of naturalistiese gedagtes, is ' $n$ positiewe transformasie. Hierdie stelling is iets anders as ' $n$ sintese tussen strydige (heidense en Christelike) gedagtes, want dit soek nie na 'n groter waarheid deur 'n eklektiese saamgooi van sogenoemde gedeeltelike waarhede nie.

Naas 'n konfrontasie beklemtoon sommige Christendenkers die moontlikheid en selfs die noodsaaklikheid van 'n gesprek met andersdenkendes. Daar moet nie net op verskille gelet word nie, maar daar moet ook na waarheidsmomente by andersdenkendes gesoek word (vgl. Stoker, 1970:41). Om op ooreenkomste te let is ook 'n vorm van kritiek. Stoker praat van ekshaeretiese kritiek wat waarheidselemente in ander stelsels ontbloot en vrymaak. So byvoorbeeld het die materialisme ook geldige punte wanneer gestel word dat materie bestaan en dat alles van materie afhanklik is. Sodra die materialisme egter sy grondoortuiging uitspreek dat net materie bestaan en alles eintlik net een of ander vorm van fisieschemiese prosesse is, dan word die skeppingsverskeidenheid tot enkel fisies-chemiese dinge gereduseer. Dit is ' $n$ verabsolutering van materie. Materie word sodoende tot die alfa en omega verklaar - iets wat volledig op sigself kan staan en aan alle ander dinge sin, doel en betekenis kan gee.

Laasgenoemde twee opmerkings toon dat die gesprek oor waarheidselemente ook 'n religieuse diepte kan ontgin. Alle wetenskaplikes het met die struktuurwette van byvoorbeeld taal, fisiese kragte, ruimte en kuns te make. Almal het egter nie dieselfde religieuse 
begronding of idee in verband met die grensvrae in hulle vak nie. In die naspeur van prosesse worstel nie-Christene ook met die moontlikhede en ordelikhede (wat God in die skepping gelê het). Wat Klapwijk en ander bepleit, is geen relativistiese pluralisme waar die een perspektief maar so goed soos die ander sou wees nie. In hierdie verband is die opmerking al gemaak dat die ongelowiges onbedoeld handlangers van Christenwetenskaplikes is wat eerder 'n skeppingsverskeidenheid wil naspeur.

Kommunikasie tussen "andersdenkendes" en "eendersdenkendes" is ook moontlik, omdat wetenskap deur geloof onderbepaald is. Uiteraard geld die volgende: credo ut intelligam - ek glo sodat ek mag verstaan. Al is die wetenskap vol bona fides, is dit nogtans geen absolute of omvattende kennis nie.

Wetenskap is meerdimensioneel en bestaan nie van $A$ tot $Z$ net uit vooronderstellings, bona fides en/of geloofskennis nie. Wetenskap is nie identies aan voorwetenskaplike lewens- en wêreldbeskouing nie. Geloof en wetenskap, geloof en teologie, geloof en filosofie kan mekaar nie volledig distribueer, uitput of vervang nie (vgl. Du Plessis, 2006:69-70).

Wetenskap is meerdimensioneel ten opsigte van die feit dat dit nie slegs met logiese waarheid te make het nie, maar ook met die kwaliteit van lewe en bedagsame verantwoordelikheid. Die betekenis van teologiese en filosofiese insigte sal dus versigtig en voorlopig uitgewerk moet word vir die samelewing waarin die mens funksioneer.

\section{Wetenskap: meerdimensioneel}

Anders as modernisme (positivisme of rasionalisme) stel die artikel dat die wetenskap 'n meerdimensionele voorkoms toon in die empiriese, logies-metodologiese en grondslaekwessies (vgl. Du Plessis, 2006:46 e.v.). Vanuit drie wetenskapsdimensies (empiries, metodologies en die dimensie van metakwessies) beredeneer die outeur dat wetenskappe geen onafhanklike, neutrale, objektiewe of veronderstellingslose toegang tot die werklikheid en tot betroubare kennis is nie. Saam met die aannames in die empiriese fase en die metodologiese kwessies van die middellaag, is daar 'n dimensie van grondoortuigings in vakdissiplines wat 'n paradigma staande hou. Van Huyssteen praat van die "narative and hermeneutical dimension of science" (vgl. Van Huyssteen, 1998:15). 


\section{- Logies-empiriese dimensie of bolaag}

Dit impliseer dat wetenskap meer as slegs 'n eendimensionele logies-empiriese aktiwiteit behels. Gewoonlik word die versameling van gegewens as die eerste of empiriese bolaag van wetenskapsbeoefening bestempel. Primêre positiviste is teen filosofie en teologie gekant wat metafisies soek na dit wat bo/onder/verder/meer is as die feite. Die versameling van gegewens word rondom 'n probleemstelling gedoen. Maar selfs die positivistiese wetenskaplike soek na meer, naamlik na die sistematisering van feite en na 'n reëlmaat wat help om verbande tussen feite te begryp en om voorspellings te maak. Die vraag, "Wat is wetenskap?", word dikwels in die empiriese ondersoek beantwoord met "ten easy steps to do science". Goeie vakkennis steek egter nie vas by die blote beskrywing of empiriese ondersoek nie. Daar word na 'n teorie gesoek om verbande tussen feite te verklaar.

\section{- Dimensie van metodologiese ordening en teoriebou, of die middellaag}

Hierdie teoretiese raamwerk lê op 'n dieper vlak as die versameling van feite. Die middellaag van wetenskapsbeoefening is gelaai met metodologiese en kennisteoretiese kwessies. Filosofie en teologie het ook die een of ander hipotese of uitgangspunt hoekom en hoe betroubare kennis oor 'n bepaalde werklikheidsgebied versamel kan word. Watter kwessies in die wetenskappe kan die sogenaamde middelvlakkwessies genoem word?

Die voorgestelde werkgroep kan na antwoorde soek deur onder andere aandag te gee aan die vraag wat dit is wat Teologie en Filosofie hulle wetenskaplike karakter laat behou. Indien kollegas op wetenskap as 'n modus operandus (van kennis) konsentreer, word metodologie die sleutel tot hoëkwaliteitnavorsing en tot geldige kennisverwerwing. Vakspesialiste lê graag op sistematiese ordening en modelbou klem. 'n Samehangende teorie skep 'n model van die deelwerklikheid wat bestudeer word. Sommige kollegas moet hulleself daaraan herinner dat ' $n$ model nie identies aan die werklikheid is nie. Dit bly 'n teoretiese konstruksie, 'n abstraksie van die werklikheid.

\section{- In elke wetenskap bestaan 'n dieptelaag van grondslae- kwessies}

Die nuwe analfabeet in ons tyd word soms 'n "vakidioot" genoem, omdat hy/sy te min kennis van sy/haar eie denkraamwerk dra om bestaande kennis en aannames te kan evalueer en heroorweeg. 
Sonder 'n denkraamwerk (paradigma) kan die nuwe wetenskaplike analfabeet nie maklik nuwe feite soek en vind nie. 'n Denkraamwerk maak 'n groot deel van die dieptelaag van wetenskaplike dissiplines uit. Dit strek selfs oor die empiriese en metodologiese dimensies.

In elke wetenskaplike dissipline bestaan daar eie grondslaekwessies. Dit is eie aan die besondere vakwetenskap en word deur die vakbeoefenaars veronderstel, geglo, ontwikkel en sistematies georden. Meestal word die kwessies as "vakfilosofiese kwessies" beskryf. Vakwetenskappe (bv. Fisika en Privaatreg) se vakfilosofiese kwessies verskil onderling van mekaar. Vakfilosofiese vraagstukke is (veral) die betrokke vakdissiplines se verantwoordelikheid.

Grondslaekwessies kom veral by hermeneuties-metodologiese debatte, grondmotiewe en vooronderstellings ter sprake. Waar vakspesialiste die vraag na wetenskap as 'n vraag na die sin, doel en gronde van kennis beantwoord, kom die religieuse sin van wetenskap ook duideliker na vore.

Vakspesialiste wat 'n kritiese vergelyking tussen skole, stromings en paradigmas in die eie vakgebied aanpak, is besig met hulle grondslaekwessies. Die vakspesialis het alles met die weeg van teorië in die eie vakgebied te make. Anders as Troost (2004:147) vind Wolterstorff (1976:61) dit jammer dat vakspesialiste soms traag is om hulle grondslaekwessies (foundational issues) self te weeg en te oorweeg:

... those who work in the sciences spend relatively little of their time weighing theories, that is, deciding whether to accept or reject them.

Tog moedig hy vakwetenskaplikes aan om 'n "analysis of the weighing of theories" aan te pak. 'n Vakspesialis se kritiese ingesteldheid teenoor die eie vak se veronderstellings, paradigmas, metodes van kennisverwerwing, toetsing en teoriebou is (behoort) wesenlik deel van die betrokke vakwetenskaplike dissipline (te wees).

Grondslaekwessies is egter ook "voer vir filosowe". Die afgelope halfeeu het baie gesprekke oor filosofiese vooronderstellings binne wetenskappe opgelewer - selfs binne 'n teologiese hermeneutiek. Die dieptelaag van vakdissiplines bestaan nie net uit vakwetenskapsfilosofiese kwessies nie. Saam met 'n vakspesifieke wetenskapsbeskouing is daar ook ander gemeenskaplike kwessies soos 'n veronderstelde werklikheids-, kultuur-, mens- en lewensbeskouing. 
Nóg Filosofie, nóg vakdissiplines het egter alleenreg op sogenaamde grondslaekwessies.

\subsection{Grondslaekwessies: wesenlike deel van die eie vak- beoefening}

Die ontginning van aannames, veral oor die aard van die vakgebied, vooronderstellings en paradigmas binne die eie vakgebied kan 'n oop gesprek tussen filosowe, teoloë en ander kundiges inlei. Die voorstel dat 'n werkgroep tussen teoloë, filosowe en ander vakspesialiste op die been gebring word, hang nou saam met die insig dat grondslaekwessies in alle fakulteite en studierigtings bestaan. Dit is teenwoordig in vakspesialiste se siening oor die aard en grense van die eie wetenskap en metodes.

Anders gestel: vakspesialiste het hulle eie sterk sienings oor die verhouding tussen teorie en praktyk, tussen die eie wetenskap en vakeie basiese aannames, veronderstellings, aksiomas, ensovoorts. Omdat grondslaekwessies 'n wesenlike deel van die eie vakbeoefening is, moet dit nie daarvan losgemaak word en alleen aan filosowe vir bestudering gegee word nie. 'n Interdissiplinêre aanpak daarvan deur Teologie én Filosofie kan groter insig en praktiese wysheid bring.

Heelwat vakspesialiste (onder invloed van positivisme?) is geneig om wetenskapsfilosofiese kwessies van hulle vakke na filosowe te verwys. Self konsentreer hulle liefs op die empiriese en/of metodologiese vlakke en laat die sogenaamde metafisiese vrae aan filosowe oor, wat graag spekuleer. Wetenskap word egter oppervlakkig bedryf indien spesialiste die talle aannames, uitgangspunte, doeleindes en selfs die werklikheidsbeskouing wil uitsluit van al die empiriese noterings, bewerkings en afleidings van feite. Vakwetenskaplikes wat hulle eie sogenaamde metavraagstukke liefs na filosowe verwys, kom (gou) agter dat hulle vakspesialisme nie sonder dieptelaagvraagstukke en dieptelaagopvattings gedoen/bedryf kan word nie. Sonder om voortydig in 'n diskussie met Troost (wie se opvatting by die meeste reformatoriese filosowe gangbaar is) betrokke te raak, word aanbeveel dat selfs die verskil in opvatting onder gereformeerde geleerdes by geleentheid op die agenda van die forum ter sprake kan kom.

Vakspesialiste kan met vrug aan hulle eie vakgekoppelde aannames en versweë bona fides aandag gee. Dit help vakspesialiste om die simbiose tussen vakkennis en grondslaekennis op te spoor en diepgang in hulle vakspesifieke ondersoeke te bereik. Vakspesialiste 
formuleer meestal aan die begin van hulle ondersoek - en dalk deurlopend - sekere pertinente vooronderstellings en aannames sodat 'n empiriese ondersoek van die grond af kan kom:

Scientists always rely on a tacit faith ... that there is a real world 'out there', that this real world hangs together intelligibly, that the human mind has the capacity to comprehend at least some of the world's intelligibility ... Without this kind of trust there could be no incentive to look for the order present in nature or to keep looking deeper into the specifics of this order. (Haught, 1995:23.)

\section{2 'n Voorlopige agenda}

- Grondslaekwessies hoort eerder op die agenda van 'n interdissiplinêre werkgroep as by 'n enkel dissiplinêre opset.

- Wetenskaplikes moet afsien van die verwagting dat Filosofie alleen en namens vakdissiplines (en ook namens Teologie) die heersende vakfilosofiese en metakwessies eie aan Teologie (en ander vakdissiplines) sal oplos.

- Teologie, Filosofie en ander vakdissiplines kan saamwerk op soek na die epistemiese betekenis van bybelse gedagtes in en vir hulle onderskeie studievelde.

- 'n Interdissiplinêre werkgroep se aandag aan die komplekse verhouding tussen geloof en wetenskap (of Christendom en wetenskap) bied 'n geleentheid om die stelling "nog wetenskap, nog godsdiens het 'n eksklusiewe reg om die komplekse werklikheid te verstaan" verder te ontgin.

- Filosofie en Teologie hoef nie na mekaar gereduseer te word nie. Daarmee saam kan die moontlikheid ondersoek word dat die onderskeid in studieterreine en -metodes moontlik naby mekaar op dieselfde spektrum lê.

- Wetenskap is nie enkelsinnig teoreties nie. Die werkgroep kan ook aan 'n nuwe wetenskapskonsep wat gelyktydig teoreties én prakties is, aandag gee. Dit kan wetenskaplikes help om hulle kundigheid as middel van 'n wysheidsmotief uit te bou.

- Indien vakkenners, filosowe en teoloë nie hulle spesialiskennis van die betrokke grondslaekennis amputeer nie, kan die voorgestelde werkgroep 'n bydrae maak tot die kwaliteit van navorsing in die betrokke dissiplines. 
- Omdat daar 'n verskil in opvatting is oor die stelling dat grondslaekwessies nie aan filosowe alleen oorgelaat moet word nie, word aanbeveel dat selfs hierdie "verskil in opvatting" by geleentheid op die agenda van die forum ter sprake kan kom.

- 'n Deurlopende redenasie van die artikel is dat grondslaekwessies veral binne 'n werkgroep aandag moet kry, omdat Teologie en Filosofie as wetenskappe met bona fides en met grondslaekwessies te make het.

Christenfilosowe en -teoloë soek wysheid (behoort wysheid te soek) in 'n bedagsame verantwoordelikheid teenoor die mens, die natuur en voor God. Sodoende kan hulle vakbeoefening ook 'n strategie word om 'n gangbare beheersingsmotief (wat wetenskap as 'n tegnologiese mag oor die natuur, die mens en die kultuur sien) met 'n wysheidsmotief te vervang wat eerder bedagsaamheid, sorg en shalom versprei (vgl. ook Wolterstorff, 1996:34 e.v.).

\section{Geraadpleegde bronne}

BERNSTEIN, R.J. 2002. Religious concerns in scholarship. (In Sterk, A., ed. Religion, scholarship, and higher education. Notre Dame: University of Notre Dame Press. p. 150-157.)

BRUMMER, V. 1992. Wijsgerige theologie in beweging. Franeker: Wever.

BYBEL. 2004. Die multivertaling Bybel. Vereeniging: Christelike Uitgewersmaatskappy.

CLAASSEN, G. 2007. Geloof, bygeloof en ander wensdenkery: perspektiewe op ontdekkings en irrasionaliteite. Pretoria: Protea Boekhuis.

DU PLESSIS, P.G.W. 2006. Wetenskap met en sonder diepte? Koers, 71(1):43-71.

ELLIS, G. 2000. Are there limitations to science? (In Stannard, R., ed. God for the 21st century. Philadelphia: Templeton Foundation Press. p. 163-165.)

GEERTSEMA, H.G. 1992. Het menselijk karakter van ons kenne. Amsterdam: Buijten \& Schipperheijn.

GEERTSEMA, H.G. 1996. Faith and science biblical perspective. (In Van der Meer, J.M., ed. Facets of faith and science. Vol. 4. Lanham: University Press of America. p. 285-312.)

HAUGHT, J.F. 1995. Science and religion: from conflict to conversation. New York: Paulist Press.

KLAPWIJK, J. 1995. Transformationele filosofie. Kampen. Kok.

NEWBIGIN, L. 1989. The gospel in a pluralistic society. Grand Rapids: Eerdmans.

NOLL, M.A. 2002. Teaching History as a Christian. (In Sterk, A., ed. Religion, scholarship, higher education. Notre Dame: University of Notre Dame Press. p. 161-171.)

OUWENEEL, W. 1995. Christian doctrine. Vol. 1. Amsterdam: Buijten \& Schipperheijn.

SLOANE, A. 2003. On being a Christian in the academy. Carlisle: Paternoster. 
STANNARD, R., ed. 2000. God for the 21st century. Philadelphia: Templeton Foundation Press.

STOKER, H.G. 1970. Oorsprong en rigting. Vol. 2. Tafelberg: Kaapstad.

TROOST, A. 2004. Vakfilosofie van de geloofswetenschap: prolegomena van de theologie. Budel: Damon.

VAN HUYSSTEEN, J.W. 1998. Duet or duel? Theology and science in a postmodern world. London: SCM.

WOLTERSTORFF, N. 1976. Reason within the bounds of religion. Grand Rapids: Eerdmans.

WOLTERSTORFF, N. 1996. Van zekerheid naar trouw: Christen-zijn en de wetenschap in een postmoderne cultuur. Vert. door B. Cusveller. Zoetermeer: Boekencentrum.

WOLTERSTORFF, N. 2002. Scholarship grounded in religion. (In Sterk, A., ed. Religion, scholarship, higher education. Notre Dame: University of Notre Dame Press. p. 3-16.)

\section{Kernbegrippe:}

Christelike denke

denkmodel

Filosofie

grondslaekwessies/-oortuigings

Teologie

vakdissiplines

waarheidselemente/metodes van kritiek

\section{Key concepts:}

Christian scholarship

elements of truth/methods of critique

foundational issues/views

paradigm

Philosophy

special sciences

Theology 
